\title{
Impacts and changes caused by the Covid-19 pandemic in librarianship: the rural school library scenario
}

Daniela Carla de Oliveira ${ }^{1}$, (iD Leilah Santiago Bufrem ${ }^{2}$, (iD Marcos Gehrke $^{3}$

${ }^{1}$ Secretaria de Estado da Educação do Paraná. Avenida Água Verde, 2140, Vila Isabel. Curitiba - PR. Brasil. ${ }^{2}$ Universidade Federal do Paraná - UFPR. ${ }^{3}$ Universidade Estadual do Centro-Oeste do Paraná - UNICENTRO.

Author for correspondence: dani.lela.com@gmail.com

\begin{abstract}
This article presents data on the impacts and changes caused by the Covid-19 pandemic on librarianship within the context of rural school libraries. We understand the work in libraries as a special activity that is only valued if contextualized. Thus, we question the role of the library and the librarian practices in the current pandemic scenario with the purpose of updating the debate on librarianship in rural schools. To this end, we conducted a bibliographic and exploratory field research mediated by the application of a questionnaire. We conclude by highlighting the precarious situation that prevents actions and activities to encourage reading and the dissemination of pedagogical resources to support school and school-community libraries.
\end{abstract}

Keywords: rural school library, pandemic, librarian.

\begin{tabular}{|l|l|l|l|l|l|l|} 
RBEC & Tocantinópolis/Brasil & v. 6 & e12478 & $10.20873 /$ uft.rbec.e12478 & 2021 & ISSN: 2525-4863 \\
\hline
\end{tabular}




\section{Impactos e mudanças causados pela pandemia de Covid- 19 no fazer da biblioteconomia: cenário da biblioteca escolar do campo}

RESUMO. Este artigo apresenta dados sobre o impacto e as mudanças causadas pela Pandemia de Covid-19 no fazer da biblioteconomia, no cenário da biblioteca escolar do campo. Apresenta o trabalho em bibliotecas como um fazer especial, cujo sentido só é valorizado se contextualizado. Questiona o papel da biblioteca e das práticas bibliotecárias na atual conjuntura, com o cenário da pandemia de Covid-19. Objetiva atualizar o debate sobre o fazer bibliotecário em Escolas do Campo na conjuntura da pandemia. Faz uso de pesquisa bibliográfica e exploratória em campo, mediada pela aplicação de questionário aos responsáveis pelas bibliotecas. Conclui apontando a situação de precariedade, impeditiva de ações e atividades de incentivo à leitura e disseminação de recursos pedagógicos de apoio às bibliotecas escolares e escolarescomunitárias.

Palavras-chave: biblioteca escolar do campo, pandemia, bibliotecário. 


\section{Impactos y cambios causados por la pandemia de Covid-19 en el hacer de la biblioteconomía: escenario de la biblioteca escolar del campo}

RESUMEN. Este artículo presenta datos sobre el impacto y los cambios causados por la Pandemia de Covid-19 en el hacer de la biblioteconomía, en el escenario de la biblioteca escolar del campo. Coyuntura el trabajo en bibliotecas como un hacer especial, cuyo sentido solo es valorado si contextualizado. Cuestiona el papel de la biblioteca y de las prácticas bibliotecarias, en la actual coyuntura, con el escenario de la pandemia de Covid-19. Objetiva actualizar el debate sobre el hacer bibliotecario en escuelas del campo en la coyuntura de la pandemia. Hace uso de investigación bibliográfica y exploratoria en campo, mediada por la aplicación de cuestionario. Concluye apuntando la situación de precariedad, impeditiva de acciones y actividades de incentivo a la lectura y diseminación de recursos pedagógicos de apoyo a las bibliotecas escolares y escolares-comunitarias.

Palabras clave: biblioteca escolar del campo, pandemia, bibliotecario. 


\section{Introduction}

Library work is a unique practice whose meaning is only valued when contextualized. Consequently, it becomes a praxis of political act, recognized through its transformative power and the meaning of these transformations to the specificities of each context. Although librarianship ${ }^{i}$ is characteristic of librarians, it transforms and transgresses into the practices of several other actors, such as teachers, activists, students, reading agents, and other professionals who still believe in the contemporary relevance of the library to a humane education.

Specifically in the case of the Work School Libraries (WSL) located in rural schools (Caldart et al., 2012), which are understood as spaces for production, ordering and circulation of information, knowledge, and rural culture, the meaning of this praxis emerges from the encounter between work and the unique contradictions of the rural context. Whether because of the absence, inadequacy, or isolation of the libraries, their distance from the cities, or the precarious access to books and librarianship, these contradictions stem from the absence of public policies aiming at the production and publication of local knowledge, as well as from the lack of professionals able to occupy these spaces and the limitations on the teaching of readers due to the inadequacy of library collections, locations, and specialized services. All these circumstances restrict the minimally conducive conditions to the development of a taste for reading in the students, which is related to "cultural and intellectual experiences, the insertion of the individual in a universe of complex relationships" (Britto, 2009, p. 26).

Ten years (2012) after our first visit to school libraries (SL) in encampments and settlements of the Brazilian Landless Workers Movement (MST), we participated in a lecture on the possibilities of librarianship in the face of the impacts and changes caused by the Covid-19 pandemic in rural school libraries. Based on this debate, we revisited the impressions and data gathered in 2012.

To this end, we used guiding questions for reflection as a research method, which prompted this study proposal. The questions included: what is the role of the library and library practices in the current situation? Are these practices being carried out? Who develops the activities, or, what is the profile of those who work in the libraries? In the case of the Paraná State Secretariat of Education and Sports ${ }^{\mathrm{ii}}$ (SEED), what is the state's 
position on these activities from 2020 to 2021?

Afterward, we conducted a bibliographic research on various sources to provide theoretical support for the study and applied a questionnaire to those responsible for rural schools located in the Agrarian Reform settlements. Four questions were asked based on the study proposal: what has been happening to SLs in the pandemic scenario? Has the state instructed school principals? If it has been working on something, what practices has your school proposed and developed using books? Who has worked in the rural SL during this period and what is the profile of this professional?

In this study, we aimed to analyze the impacts and changes caused by the Covid-19 pandemic in the librarianship of rural schools and identify the profile of those who work there. Thus, this study articulates the path taken in previous research, provides an update to the period after the questionnaire application in the rural schools, and materializes the reflections from the lectures carried out and the collaborative writing of this text.

It is organized into three sections. Firstly, we address the exploratory study that brought us closer to libraries in rural contexts (2012). In the second section, we reflect on librarianship in the context of rural schools. In the third, we analyze the questionnaire data and the context of the pandemic in the current situation of the rural SLs. We conclude with the final considerations and references.

\section{Exploratory study: research in the rural context}

To carry out their exploratory studies, Gehrke and Oliveira (2012), then doctoral students of the Graduate Program in Education at the Federal University of Paraná (UFPR), traveled to Cascavel and Rio Bonito do Iguaçu, in Paraná state, to visit the rural schools located in the settlements and encampments from the MST's Agrarian Reform.

By retaking this path, we evoke the memories of the field, our journey, the ones who fight for the school, and the rural SLs and their facilities, some of which were improvised and limited by structural conditions and lack of specialized staff. We gradually recognized this scenario due to the efforts of Gehrke (2014), whose four-year work stimulated knowledge, adoption of both modes of organization and use of collections, creative practices, and the transformation of attitudes towards libraries, reading, and writing processes. Thus, this deliberate action gradually had its results recognized and expanded - the main results being the two theses defended, 
respectively, by Gehrke (2014) and Oliveira (2014).

Gehrke's thesis (2014) analyzes the SLs of the Paraná State's Rural Education network in relation to the context of the Rural Education Movement (Caldart et al., 2012) through a case study that uses context and content analysis. The author addresses the contradictions perceived in this scenario and defends that writing is a way of fighting and working.

He recognizes the advance of information science and the improvement of systems related to it, emphasizing, among other media resources, educational technologies and electronic books. Furthermore, his thesis points to possibilities for the SLs in the context of rural education, as well as for the development both in school and WSLs of organic intellectuals - readers and writers -, which emerge, according to Gramsci (1984), from the process of development of the social class they are connected. It also contributes to the praxis in order to transform the rural SL into rural WSL; aims to understand the relationship between the context of rural education, public policies, and the production of the library collection originated from this conflict (1998 to 2013); characterizes the SLs of Paraná, their physical and political space, their library collections, and the work of their actors; conceives educational guidelines for the actors who work in the WSL; and suggests principles for the WSL production. The author ordered the bibliography using the Brapci, Capes, Unicamp, and Unespar databases and organized his thesis into theoretical categories: SL, WSL, Rural Education, Culture, Knowledge, Collective Organization, and Work.

Empirically, he produced data from the analyzed documents that stemmed from the Rural Education Movement (1998 to 2013) and initiated, based on the inventory created, a critical elaboration on reality or, in other words, the product of the historical process developed until now (Gramsci, 1984, p. 12). His study identifies a growing investment in research and public policies both in information science and the production of information technologies, contrasting with the frequent marginalization of the educational field.

In addition, Gehrke (2014) addresses the advances in the formulation of policies and legislation on books and SLs, but also identifies contradictions in their implementation, emphasizing the lack of universal access to Paraná's public school's libraries, as provided by Law No. 12,244 from May 24, 2010 (Brasil, 2010).

He argues that the contributions of social movements - especially the MST - 
and the production of an organized library collection in rural schools provide considerable contributions to the prominence of the WSLs, among which stand out the praxis of collective writing led by the subjects of struggle, processes of systematization of experiences, publication and circulation of the produced documents, and writing of various discourse genres.

His thesis highlights unfavorable elements to the praxis in the SLs and, simultaneously, enables creation and transgression, revealing the need to build the SL within its reality and in a feasible conjuncture. To achieve this goal, the engagement of all the educational community members is necessary, even if it is low, as well as a possible and appropriate organization of the SL through adequate and pertinent planning and its establishment as a permanent issue for both rural and educational social movements. Gehrke's (2014) thesis played a transformative role that highlighted the impact of such studies and, therefore, their relevance to the praxis in rural SLs.

Oliveira's thesis (2014), in turn, is based on an exploratory study carried out in rural schools of Paraná's MST encampments. The author applied two questionnaires - one to pedagogical coordinators of MST's Itinerant Schools and the other to educators who teach the final years of primary and secondary education -, totaling nine schools and 40 participants.

Developed between 2011 and 2014, the study identified the Itinerant Schools' conceptions and reading practices that were transferred to the encampment, as well as the reading practices of the encampment that were transferred to the schools, demonstrating that the cultural reading practices are interrelated within this territory. Oliveira focused on the relationships established at schools and in the MST encampment that stemmed from reading, revealing - in a historical rescue of the Itinerant Schools' political and pedagogical aspects - a fighting process on behalf of schooling and education, the political-pedagogical organization, and the implementation of the Human Formation Cycles and the Study Complexes.

Moreover, she analyzes conceptions and strategies on reading, the library, and its collection, proposing an understanding of the Itinerant School's reading process through four categories: the educator and their relationship with reading; the training of educators on reading encouragement; the occurrence conditions of reading practices; and the meaning of reading both in the school and the encampment. The two theses converge on the construction of school knowledge and practices, 
emphasizing the reading practices in school and library contexts.

Therefore, based on the social practices carried out in the daily life of this social movement, we deduce that the construction of knowledge and school practices, such as the practice of reading and writing, occurs in an environment surrounded by social, political, and economic uncertainties and pressures. As Gehrke and Oliveira observed, this is confirmed by the social practices of the struggle for land, education, and schooling that occur in the MST's daily life, as we will demonstrate in the following section.

\section{Librarianships: from the worker and their profile to the practices in the rural school library}

We understand that the library is a social and human construction driven by labor (Marx \& Engels, 1986). Work modes performed in the SL - that is, librarianship or praxis (Freire, 1987) - are concepts that support our perspective of construction and fight for the SL within the rural context (Caldart et al., 2012). According to our study, a set of actors participate as workers in the SL scenario: "specific professional", "librarian", "reading agent", "secretary", "library attendant", "person in charge", "employee", "pedagogue", "principal", "teacher", "readapted teacher", "educational agent", "volunteer worker".
Article 3 of Law No. 12,244 from May 24, 2010, which provides for universal access to libraries, states that "the country's education systems shall develop progressive efforts so that the universal access to SLs, under the terms set forth in this Law, be accomplished within a maximum period of ten years, respecting the Librarian profession" (Brasil, 2010).

This deadline has not been met, which, according to Pereira (2018), results from the lack of actions aimed at its fulfillment, schools' infrastructure, and professionals contributing to the creation of the SLs and their effective management. Although the author observed wellfounded ideas regarding the role of libraries at schools, especially in relation to the reading and literacy process, he did not identify political support for their implementation.

Both the empirical data and the legislation prove that teachers are hired to work in the classroom; pedagogues and principals to work with pedagogical and administrative management, respectively, and all other professionals to exercise specific activities. Thus, we question: why does the state of Paraná not hire professionals to work in public SLs? Would the actors present in the school library today have the political-technical 
expertise to perform this function? Is there no legislation on this issue?

In this regard, we verified that, after the deployment of the Public-School Libraries Network System (Paraná, 2011), SEED's Resolution 4,534/2012, determined the use of Pergamum software for this proceeding in order to computerize and integrate the library collections. SEED selected 500 schools to participate in a pilot project, which aimed to deploy the system and establish a demand for hiring reading agents for all the SLs' shifts (Paraná, 2011). According to the document, the reading agent must present reading skills and taste for reading, be a school staff member, such as an administrative agent or readapted teacher, and participate in the program's training. The SEED website announced three training courses in 2012, after which nothing was offered to comply with the Resolution. The system deployment was then abandoned without any explanation to the schools. In order to verify if there was any attempt between 2013 and 2021 to restart the debate on the SLs and SEED, we consulted the "Teacher's Channel" (2020), an online tool that aims to promote dialogue, experience exchange, and the continuing education of teachers of the Paraná education network during the pandemic. We verified that, in 2020, only one of the countless videos posted daily on the Channel addressed librarianship in schools. The video, entitled "Conexão Professor: A BE engajada no incentivo da leitura" (Teacher Connection: The SL engaged in encouraging reading), reports the experience, organization, and promotion of reading in the library of the public-school José de Anchieta, located in União da Vitória. This finding demonstrates the absence of policies aiming at SLs' work and workers. Therefore, we start by emphasizing the need to establish the profile of those who work in the SL: workers who, in their educational practices, articulate school and life, work and study, and information and knowledge.

However, the fight for a clearly defined profile of this subject and their performance in the SL needs to be a joint action between education workers, social movements, Higher Education Institutions (HEIs) and SL actors. In the rural school context, their current profile is widely diversified, which means a lack of definition. The SL has served as an educational space within schools without the presence of professionals trained for this purpose and, thus, it has been discredited and devalued in the educational system. 
Taking this action as one of WSL's operating principles implied bringing the investigated context to a situational analysis, that is, the reality of the rural school library, based on the statements collected in this research from those who work in the SL, as well as the data available in the literature, which resulted in Table 1.

In the first column, we name the actors who work in rural SLs, with data from the questionnaire gathered from 355 rural schools in 2014. In the second column, we present their training and position within Paraná's public school system, based on SEED's documents and on the responses of the rural SL workers to the questionnaire (2021). It is worth noting that none of them are officially hired to work in the SL, but they all engage in these practices and have skills that point towards a potential profile. Finally, in the third column, we provide a synthesis or characterization of what would be the profile traits of the WSL worker based on the literature studied and the WSL project.

Three major dimensions of their profile pose a challenge in the training of WSL workers: the professional dimension and their recognition as a working class; the political dimension that outlines their work in this sphere of human development; and the pedagogical dimension, as a shaper of the cultural and school environment. These workers go through a formative process in the library's daily practice, in initial and continuing education in public universities, and are appointed by the State as SL workers.

Table 1 - Relationship between the SL actor, their profile, and the profile of the WSL worker.

\begin{tabular}{|c|c|c|}
\hline SL actor & Profile of the SL actor & Profile of the WSL worker \\
\hline $\begin{array}{l}\text { Library } \\
\text { attendant } \\
\text { Employee } \\
\text { Educational } \\
\text { Agent II } \\
\text { Secretary }\end{array}$ & $\begin{array}{l}\text { Worker. Professional. } \\
\text { Profession recognized in the } \\
\text { public education system. Public } \\
\text { tender. Technician in the field. }\end{array}$ & \multirow{5}{*}{$\begin{array}{c}\text { Worker } \\
\text { Profession recognized in the public education } \\
\text { system. } \\
\text { Permanent employee } \\
\text { Technician or Graduate in the field } \\
\text { Manager } \\
\text { Leadership } \\
\text { Experienced Person } \\
\text { Educator } \\
\text { Popular Educator } \\
\text { Political agent } \\
\text { Cultural entertainer } \\
\\
\text { School librarian }\end{array}$} \\
\hline Librarian & $\begin{array}{l}\text { Worker. Professional. Graduate } \\
\text { in the field. Technical } \\
\text { preparation. Reading mediator. }\end{array}$ & \\
\hline Reading agent & $\begin{array}{l}\text { Worker. Experience in the field. } \\
\text { Reading connoisseur. Reading } \\
\text { mediator. }\end{array}$ & \\
\hline Pedagogue & $\begin{array}{l}\text { Worker. Professional. } \\
\text { Profession recognized in the } \\
\text { public education system. } \\
\text { Coordinator. Graduate in the } \\
\text { field. Public tender. }\end{array}$ & \\
\hline Principal & $\begin{array}{l}\text { Worker. Manager. Leadership. } \\
\text { Position recognized in the }\end{array}$ & \\
\hline
\end{tabular}




\begin{tabular}{|c|c|c|}
\hline & public education system. & Reading mediator \\
\hline $\begin{array}{l}\text { Teacher and } \\
\text { Readapted } \\
\text { teacher }\end{array}$ & $\begin{array}{l}\text { Worker. Professional. Reading } \\
\text { mediator. Someone who } \\
\text { teaches. Experienced Person. } \\
\text { Profession recognized in the } \\
\text { public education system. } \\
\text { Graduate in the field. Public } \\
\text { tender. }\end{array}$ & $\begin{array}{c}\text { Reading connoisseur } \\
\text { Pedagogue } \\
\text { Coordinator } \\
\text { Technician and intellectual } \\
\text { Reader's intellectual guide } \\
\text { Person acquainted with the user or user } \\
\text { community }\end{array}$ \\
\hline $\begin{array}{l}\text { Volunteer, } \\
\text { Militant }\end{array}$ & $\begin{array}{l}\text { Worker. Volunteer. Militant. } \\
\text { Someone from the community. }\end{array}$ & $\begin{array}{c}\text { Person acquainted with the school apparatus. } \\
\text { Literacy Teacher } \\
\text { Informer } \\
\text { Tutor }\end{array}$ \\
\hline
\end{tabular}

Source: the authors.

The principle that encompasses the three training dimensions reaffirms the need for a specific professional to work in the rural or urban SL. Such professional takes on roles of a librarian, but is resignified in the role of a school librarian who, for Silva (2003), incorporates characteristics of a pedagogue; hence, a pedagogy of reading. The relationship between library and reading in the intellectual work of those who work in a library is prevalent in works by Silva (1986; 1988; 2003), Milanesi (1986), and Arguelles and Zapata (2002), who insist on the qualification of both this work and the worker. This qualification may be the fine line between creating or not creating a taste for reading in the students.

Hence, this function needs to be performed by an academically trained professional, recognized by the public education system and with specific training in the field. The literature analyzed depicts this worker as a librarian, pedagogue, or educator also in the works of Llano (1997) and Freire (1984; 2001).

Campello et al. (2005), among others, highlight the broad, complex, and challenging characteristics of this worker's profile. They permeate the technical, pedagogical, and political work, characterizing this professional as a political, reader, coordinator, technical, and intellectual agent, as well as an intellectual guide for the reader, someone who knows the user community and the school apparatus, a cultural entertainer, and an informer.

For Souza (2009), Maroto (2009) and Campello et al. (2005), the library worker needs to understand their work as part of the educational practice, whose realization requires planning and conditions of execution so that its purpose - school research, reading, socially necessary work, autonomy - is attainable.

For the WSL, other aspects shape the definition of this worker's profile. We highlight their political commitment and 
militancy in the cause of rural SLs and their role as leaders and popular educators, since the WSL stands as an open space to the community (Rigobelo \& Di Giorgi, 2009), transgressing the establishment. It serves students and becomes a space of information, knowledge and culture in the broad sense (Milanesi, 1986; Maroto, 2009) for all actors of the school and its surroundings.

Regarding librarianship, some of the practices performed in the rural SLs, according to Gehrke (2014), are: to organize the available space in the school and name it SL; to choose a meaningful name for it and hold a big inauguration party; to organize the library collection and guide students and teachers to use it; to computerize the data; to plan the work in partnership with the subject-actors, taking in needs and interests; to organize the students' self-organization process and divide the work of the WSL; to map reading interests; to produce and approve, in an assembly, the SL's regulations; to publicize the collection with the community; discuss and claim the collection with the competent agencies; to claim resources to publish local production; to promote reading practices, such as seminars, recitals, reading rounds and storytelling; to tell local stories; to bring writers and people who write to give testimonials in the SLs; to bring the elders to the SL to act as storytellers; to teach school research in the SL and in the classrooms; to build the memory of the settlement, through writing and image; to transform the SL into a WSL.

However, fundamentally, this worker needs to be open to transgress the SL, creating a WSL that must articulate the schooling and de-schooling of their work, aspects that are still challenging during the Covid-19 pandemic. This leads to the question: what have the rural SLs accomplished during this time?

\section{Covid-19 as an event: impacts and changes}

The link between the data presented in the literature and the questionnaire, along with the context of the pandemic as an event that led to a series of transformations, shows how this event triggered perceptions and reactions as responses to the needs of the actors, given the already scarce possibilities in rural schools, which became even more limited. This scenario fertilizes the forces driven by social and economic inequalities.

Based on situational analysis (Souza, 2009), we have the scenario of the rural schools, especially those in settlements, with school and library actors, teachers, students, support staff, and institutional 
bodies, called subject-actors - with emphasis on the SEED of Paraná, in the current case.

In a lecture exactly one year ago, Silva (2020) made a historical overview of the theme and debated on new formats to attract the public, aiming to preserve the image of libraries as living cells of knowledge. According to the speaker, there would be no point in a SL without students and teachers, thus the big challenge would be to find a possible interface to attract the public during the pandemic. This is because "reading should not be related only to the written book", but also to other formats such as cordéis, images, and audios (Silva, 2020). The meeting raised reflections on the impacts of the pandemic on educational work and showed the need for virtualization of activities through software, digital technologies, and changes in social interactions between teachers, librarians, and students. Even though his suggestions were foreseen for a pandemic period, they are still valid and have been thought during a period of construction of differentiated practices and the rethinking of these practices in a scenario of seclusion and confinement, such as the scenario of a MST settlement, in which the temporariness stands out as much as in a pandemic.
These considerations about the possibilities of hybrid interactions in organized spaces for reading and knowledge production may suggest ways of adapting and reconfiguring the SL, "transforming them into spaces of inclusion for both traditional actions related to art and culture, as well as digital content" (Silva, 2020). Aside from the traditional actions that are susceptible to becoming remote and already foreseen for pandemic times, he presented ways of organizing the printed content using technological tools, whose potential to win over the students has expanded to the point of encouraging practices of scientific initiation, incentive to reading, culture, and citizenship.

If studying in rural schools has always demanded and continues to demand effort and persistence, because the conditions have not been favorable for those who seek to learn letters and numbers, one can only imagine in times of pandemic, when libraries lose their space to the virtual world. In this sense, there are situations in which Portuguese Language teachers, in an attempt to stimulate reading and access to digital books, organize links in "virtual libraries", which contain works of various genres selected by each teacher. These are available in their private Google Drives, taking advantage of the fact that 
publishers and authors are providing free access to their productions.

From the perspective of rural schools in Brazil, we must also highlight that in recent years they have been shut down and many children and teenagers have migrated to schools far from their homes, in a movement called nucleation or closing of schools. Hammel et al. (2021) bring current data on the closure of state and municipal public schools in the state of Paraná, indicating that the most intense period of this practice was the 1980s and 1990s, when the phenomenon of rural to urban exodus and the school transportation policy favored the closure of rural schools. Those who were not closed were subject to nucleation, multigrading, among other means used by the government to optimize the public education system. Similar research (Reichenbach, 2019) indicates that, from 1997 to 2017, 4,083 rural schools were closed in Paraná alone, and over 55,000 schools throughout Brazil.

Another difficulty not restricted to teaching practices in rural areas is the digital exclusion, a situation that favors social inequality. According to the ICT Households 2019 survey, released by the Brazilian Internet Steering Committee (CGI.br), through the Regional Center for Studies on the Development of the Information Society (Cetic.br) (2020) of the Núcleo de Informação e Coordenação do Ponto BR (NIC.br), three out of four Brazilians already use the internet, meaning that Brazil has 134 million internet users $-74 \%$ of the population aged 10 years or older.

Despite the growth in the Brazilian population that uses the Internet, about a quarter of the individuals (47 million people) are still offline. For the first time in the survey's historical series, more than half of the population living in rural areas declared they were Internet users, hitting the 53\% mark. However, a significant contingent is still unconnected: 35 million people in urban areas (23\%) and 12 million in rural areas (47\%). Among the population, there are almost 26 million (43\%) non-users.

Mobile phones are the main device for Internet access, used by almost all network users (99\%). The survey also highlights that $58 \%$ of Brazilians access the network exclusively through mobile phone, a proportion that can reach $85 \%$. The exclusive use of mobile phones also predominates among the black (65\%) and brown (61\%) populations, compared to $51 \%$ of the white population. According to ICT Households, there was a growth in network use through Smart Tvs (37\%), representing an increase of seven 
percentage points compared to 2018.

Cetic.br. also points out that:

With social isolation, a preventive measure for Covid-19, millions of Brazilians have come to rely even more heavily on the Internet and ICTs in general to conduct remote work activities, distance learning, and even to access emergency government assistance. But the lack of Internet access and the use of mainly mobile phones, especially in classes $\mathrm{D}$ and $\mathrm{E}$, show the digital inequalities present in the country, and pose relevant challenges for the effectiveness of public policies to confront the pandemic. The schoolage child population in vulnerable families without Internet access is also greatly affected in this period of social isolation. The pandemic clearly reveals the inequalities in Brazil (Cetic.br., 2020).

The study also highlights that $43 \%$ of rural schools said they do not have Internet access due to lack of infrastructure in the region, and $24 \%$ pointed out the high cost of the connection. Furthermore, while in urban areas $98 \%$ of schools have at least one computer with Internet access, in rural schools this rate drops to $34 \%$. The same survey pointed out that among the illiterate population or those who only attended early childhood education, 83\% have never accessed the network. For the people who have only completed elementary school, the rate drops, but it is still a high 35\%.

A survey conducted in Borborema (SP) by the Association of Family Agriculture and Agroecology (AS-PTA)
(2020) presents data from a field study on the situation of remote education in 11 municipalities. The testimonies corroborate: teachers are tired from the amount of activities and from dealing with the technology that many of them were not so familiar with; parents are exhausted from also taking on the role of mediator in their children's studies, when many of them do not have the proper education to do it.

"It's a very delicate situation. Parents found themselves under pressure. They have no obligation to teach but to provide schooling and opportunity for their children to study. And remote teaching is not the same, it doesn't have the same results. Video calls are just too exhausting. Sometimes we ask a question to the children and can hear someone telling them the answer. It's extremely delicate what we have to deal with," confesses teacher Jaqueline Moreira de Brito, who has been teaching for 16 years in rural schools (AS-PTA, 2020).

In this sense, some institutions have been contributing to overcome this problem faced by families and schools. Founded 25 years ago, Recode is a civil society present in nine countries with 1,152 digital empowerment centers, having reached over 1,752 million people. It works in partnership with community centers, public schools, and libraries to develop young people's digital skills and socioemotional competencies, stimulating 
the new generation's protagonism and potential as agents of social transformation. The organization's goal is to increase opportunities for young people in socially vulnerable situations through the qualified and conscious use of technology, perceiving the library as a receptive place with open doors to engage the community in literary and educational activities. Even with the pandemic outbreak and the consequent need to close spaces or adapt them, the work did not stop. The institutions showed a lot of creativity in online engagement through Recode's Home Libraries Challenge ${ }^{\mathrm{iii}}$.

In a different scenario, the quilombola community Moinho Velho, located in the municipality of Senhora do Porto (MG), was also a target of research in this period, as shown in Gomes' study (2021) featuring the report of Laisa Soares, 18 years old: "They said I graduated. But actually, I only had a few school activities last year. High school is over for us. Now, we are left waiting for a job as a nanny or house cleaner". As we can see from Laisa's trajectory, while many are preparing to enter universities at her age, the reality of young people who live in the quilombo is different.

This community was one of the three visited by the Federação das Comunidades Quilombolas do Estado de Minas Gerais
$\left(N^{\prime} G o l o\right)^{\text {iv }}$, a state organization, and the Brasil de Fato Newspaper. The young quilombola girl shares her concerns regarding her education: "How am I going to prepare for the National High School Exam? I basically skipped the last year of high school. They simply sent me some activities and I passed," explains Laisa Soares.

As a result of the pandemic, schools have switched to online classes, which are inaccessible in Moinho Velho and many other quilombola communities due to lack of internet connection. "We get access to the internet here through our cell phones. Sometimes you can watch a couple of videos on YouTube and use WhatsApp. But that's about it," says the student.

The pandemic worsened a longstanding problem in the community: young people who do not complete their studies. The schools in the region do not prepare students, such as Laisa, to enter university. She was even unaware of her right to the quota policy and financial aid granted by public universities for low-income students.

The reality described by Laisa is unfortunately not an exception; on the contrary, in pandemic times, it seems to have become the rule. Evidence is found in teachers' reports in digital media who, based on empirical observations of their 
daily pedagogical practice in virtual classrooms, verify that most of those who have access to the internet live in the city. In small municipalities, on the other hand, the internet connection is not always available to everyone and the signal quality is poor, especially in the countryside. For these students, printed activities and textbooks are left as the only resources. They were also segregated from the city during the pandemic, as many depend on school transportation and thus have no means of accessing the school or the municipal library.

Through Laisa's account, we observe that getting a job comes before finishing high school in many cases - and, particularly, during the pandemic, which has contributed to young people from both the countryside and the city, but especially the former, to enter the informal labor market. They become the cheap, unskilled, and needy workforce, looking for a source of income to help their families, which are currently unable to sell the extra production at a farmer's market, for example. Some start working on the farms, while others seek the much-desired financial independence. For these reasons, they end up choosing to work rather than going to school, which reduces school time and, as a result, reading time for many of them.
In light of these considerations, schools are facing new challenges brought by the pandemic, such as the need for remote activities and a new approach to SL. As a way to justify and articulate the practice of WSL, we highlight Milanesi's statement (1986, p. 233) referring to the extent of a library's usefulness, given how it plays a part in the population's collective actions. It is public, at the service of the public, and can only be useful if it relates dialectically to this public.

The idea of developing a "flash interview" came from the difficulty of contacting library workers - the people in charge of organizing and coordinating activities related to librarianship - amid the precarious conditions of each school, made even worse by the pandemic. Thus, the request for collaboration with the research on "the possibilities of librarianship in the face of Covid-19 impacts in rural school libraries" was sent to rural SL workers or the schools' principals. We asked for written answers to the questions listed below, along with the agreement that the data would be shared in an investigative report and a scientific article.

The answers to the first question reinforce what has already been said about the libraries' critical situation. When questioned about what has been going on with rural school libraries during the 
pandemic, the answers vary, but the nature is the same: School number 1 refers only to the exchange of books when students came to pick up school lunch or printed materials throughout 2020; School number 2 stresses that the library is closed, but the educators are arranging reading materials and books for each child to read at home; in School number 4, some Portuguese teachers conducted discussions with the students based on digital pieces, but the library remained closed.

School number 3 points to a lot of difficulty with the library's organization. The government's decision to outsource employees, combined with the pandemic, led to no administrative staff being hired so that all current employees were reassigned to printing, sorting, and delivering activities for remote teaching, as well as to distributing lunch to the families. This is a current way of setting SL aside in the organization of pedagogical work. School number 5, in turn, introduces a new situation, indicating that "there was no demand from the students and no projects from the administration and coordination to encourage reading during this period", showing that the rural school library has not yet been accepted as an educational environment. There was a large investment in printed activities, and not even the textbooks, with all their influence on teaching, managed to remain useful during the pandemic.

School number 7's answer was that "there was no orientation for reading or loaning books. It was our fault, but we can do it this year." The research raised the possibility of the library and its collection contributing in such a context, which means that the library needs to update and specialize itself in different contexts or realities.

As for the state's position on whether or not to use the school library, we found that there was a lack of guidance. School number 1 indicates that the state "Didn't touch the subject other than to say the library had to stay closed"; School number 2 also claims that "There was no instruction from the state or municipality".

In relation to the activities of school libraries during the pandemic, we asked the rural schools if they had been conducting any educational, pedagogical, or formative work. School number 1 says that "The school employees change every year and the new ones have no background in librarianship, they follow the school's guidelines and demands", which is evidence that the old problem remains. School number 3 reports that "... every other week throughout the 2020 school year, students took a book home every time they submitted an activity. They 
would also take a reading sheet to make some short observations." They add that "however, due to the pandemic, we did not allow the student to choose the book, as the asepsis of the material was not possible and we do not have gloves to provide so the students could handle it". School number 6 indicates that the library is rarely needed, as only "research and literature books chosen by the teachers and given to the children" are used. "Because WhatsApp is being used for teaching, the teachers are posting reading suggestions, links for research, and videos". School number 7 takes the opportunity to make a complaint: "It would be interesting to point out that we don't have a librarian. The role of encouragement and incentive is left to the educators. The pedagogical team and the secretary often organize the library space with the help of the community".

As for the question of who has been working remotely in a rural school library during the pandemic, the schools are unanimous in saying that they do not have librarians, and who does the work is currently a school employee (agent II); in other cases, the teachers themselves or the principal. They are also unanimous in saying that with remote teaching, these professionals are reassigned to printing activities and the library is closed. We can see the limitation of understanding (Freire,
1987) of those who run the school regarding the library collection and its use. Systematized knowledge is locked away once again, and "isolated" activities take over. Reading books gives way to "reading sheets" and what is worse: despite the law that makes libraries mandatory in schools, it still does not count with specific SL workers.

As we can see, the pandemic was a strong detriment to librarianship, and the challenges of school policies and practices regarding books and reading still remain in specific contexts.

\section{Considerations}

If the situation was already unfavorable for the rural schools - with the threats of closing, nucleation, and clustering of classes and shifts -, the pandemic and the synchronous and asynchronous remote classes had great impacts on both teachers and students. Schools were certainly closed to other dimensions of the educational and formative process.

Remote teaching has replaced the classroom with the screen and the loneliness of those who only have access to printed materials to secure their school year. With no doubt, these new ways of "learning" have a great impact on both teachers and students, and those who have 
access to the internet, however precarious, have been challenged to use digital technologies extensively.

As for the teachers, they must fulfill their workload, be it 40,30 or 20 weekly hours, on top of a series of other tasks of bureaucratic nature that take the focus off the pedagogical work. Digital technologies have also acquired new functions; besides giving access to education in pandemic times, they also serve as a form of control. By issuing data, they bring into question the teachers' autonomy, the veracity of the time spent working, and the students' learning. In rural schools, the dynamics of synchronous remote teaching are almost unfeasible, putting the students in a new situation of exclusion.

The encouragement to use digital technologies would be positive if public and educational policies had provided the conditions for it. The complaints in the questionnaire highlight precisely the limits imposed by the lack of a reliable internet connection in rural contexts that strongly impacts the lives of farmers, indigenous people, and quilombola schoolchildren, among many other peripheral subjects.

The analysis of this situation, considering the documentation and bibliography related to the problem of school library workers, allowed us to conclude that it was aggravated by the pandemic. Not even agent II is currently working in this area, as they were reassigned to work with printing and the organization of remote activities, among other tasks imposed by the lack of employees, such as controlling the gates of the institutions. The precarization of teaching material has favored the use of workbooks instead of textbooks, which have been shelved in some situations, while in others they are the only resource the students must complete their printed activities. Literary works were given more space and, in many cases, distributed for reading, while reading on a cell phone or a computer has strongly taken the place of reading printed books, an aspect that may favor the development of policies to produce of digital books for the library collection and, consequently, for librarians.

Given the results of the analysis of the questionnaire, the comparison between them, and the data provided by the theses, it is clear that after ten years of our visit to the rural schools - and despite Law 12.244 -, the reality of SL, librarianship, and the situation of the librarian in the state of Paraná remains unchanged in terms of structural aspects and absence of effective policies to support reading practices. Although the context of social isolation and technology-mediated teaching may signal the creation of alternative conditions 
that ensure the role of libraries as carriers of information and knowledge, this has not been the case, despite the efforts of some interviewees. We observed that the already precarious situation is getting worse and preventing actions and activities capable of encouraging reading and disseminating pedagogical resources to support the school libraries and school-community libraries. The pandemic, despite all the necessary measures for the collective good, has brought weaknesses to light and, among them, those involving the practices at school libraries.

\section{References}

Arguelles, J. D., \& Zapata, D. Á. (2002). Lecturas sobre lecturas. México: Conaculta.

Associação de Agricultura Familiar e Agroecologia (AS-PTA). (2020). Como está o ensino remoto nas escolas do campo nesta pandemia? Recuperado de: http://aspta.org.br/2020/10/28/como-estao-ensino-remoto-nas-escolas-do-camponesta-pandemia/

Bufrem, L. S., Gehrke, M., \& Oliveira, D. C. (2012). Relatório do estudo exploratório da pesquisa. Curitiba: [s.n.].

Bufrem, L. S., Gehrke, M., \& Oliveira, D. C. (2012). Relatório do estudo exploratório da pesquisa. Curitiba: [s.n.].

Britto, L. P. L. (2009). Educação linguística escolar: para além das obviedades. In Correa, D. A., \& Saleh, P. B. O. (Orgs.). Estudos da linguagem $e$ currículo: diálogos (im)possíveis (pp. 7889). Ponta Grossa: UEPG.

Canal do Professor. (2020). Conexão Professor: a biblioteca escolar engajada no incentivo da leitura. [Youtube]. Recuperado de: https://www.youtube.com/watch?v=Pe7K1 C84jr4

Centro Regional de Estudos para o Desenvolvimento da Sociedade da Informação (Cetic.br). (2020). TIC Domicílios 2019. Recuperado de: https://cetic.br/pt/noticia/tres-em-cadaquatro-brasileiros-ja-utilizam-a-internetaponta-pesquisa-tic-domicilios-2019/

Caldart, R. S., Pereira, I. B., Alentejano, P., \& Frigotto, G. (Orgs.). (2012). Dicionário da educação do campo. Rio de Janeiro, São Paulo: Escola Politécnica de Saúde Joaquim Venâncio, Expressão Popular.

Campello, B. S., Carvalho, M. da C., Andrade, M. E. A., Vianna, M. M., Caldeira, P. T., \& Abreu, V. L. F. G. (2005). A biblioteca escolar: temas para uma prática pedagógica. Belo Horizonte: Autêntica.

Freire, P. (1984). A importância do ato de ler: em três artigos que se completam (8. ed.). São Paulo: Cortez.

Freire, P. (1987). Pedagogia do oprimido (17. ed.). Rio de Janeiro: Paz e Terra.

Freire, P. (2001). Ação cultural para liberdade e outros escritos (9. ed.). São Paulo: Paz e Terra.

Gehrke, M. (2014). Contribuições da práxis para a constituição da biblioteca escolar do trabalho a partir da Educação do Campo (Tese de Doutorado). Universidade Federal do Paraná, Curitiba. 
Gomes, M. (2021, 11 de março)._Com pandemia, quilombolas perdem renda e têm trajetória escolar interrompida. Brasil de Fato, Belo Horizonte. Recuperado de: https://www.brasildefato.com.br/2021/03/1 1/com-pandemia-quilombolas-perdemrenda-e-tem-trajetoria-escolarinterrompida

Hammel, A. C., Ferreira, E. M., Gehrke, M., \& Finatto, R. A. (Orgs.). (2021). Escolas multisseriadas do Paraná: um estudo a partir do programa Escola da Terra. Curitiba: CRV.

Lei n. 12.244. (2005, 25 de maio). Dispõe sobre a universalização das bibliotecas nas instituições de ensino do País. Brasília, DF: Presidência da República. Recuperado de:

http://www.planalto.gov.br/ccivil_03/_ato2 007-2010/2010/lei/l12244.htm

Llano, X. (1997). La biblioteca en el medio rural: reflexiones. Madrid: Trea.

Maroto, L. H. (2009). Biblioteca escolar, eis a questão: do espaço do castigo ao centro do fazer educativo. Belo Horizonte: Autêntica.

Marx, K., \& Engels, F. (1986). A ideologia alemã (5. ed.). São Paulo: Hucitec.

Milanesi. L. (1986). Ordenar para desordenar: centros de cultura e biblioteca pública. São Paulo: Brasiliense.

Oliveira, D. C. (2014). Práticas de leitura na Escola itinerante do Movimento dos Trabalhadores Rurais Sem Terra, Paraná (Tese de Doutorado). Universidade Federal do Paraná, Curitiba.

Paraná. (2011). Projeto Implantação dos Sistemas da Rede de Bibliotecas Escolares Públicas. SEED/SUED. Curitiba: [s.n.].

Pereira, R. (2018). A Lei n. 12.244/2010 e seus desdobramentos no estado de Mato
Grosso do Sul, Brasil. Páginas $A \& B$, Arquivos e Bibliotecas (Portugal), 9, 8097.

https://doi.org/10.21747/21836671/pag9a5

Reichenbach, V. (2019). Fechamento das escolas do campo no estado do Paraná (1997 - 2017): violação do direito a educação (Dissertação de Mestrado). Universidade Federal do Paraná, Curitiba.

Rigobelo, A. P. C., \& Di Giorgi, C. A. G. (2009). Outros parceiros na biblioteca escolar: democratização e incentivo à leitura. In Rigobelo, A. P. C., \& Di Giorgi, C. A. G. Biblioteca escolar e práticas educativas: os mediadores em formação (pp. 76-92). Campinas: Mercado das Letras.

Silva, E. T. (1986). Leitura na escola e na biblioteca. Campinas: Papirus.

Silva, E. T. (1988). Elementos de pedagogia da leitura. São Paulo: Martins Fontes.

Silva, E. T. (2003). O bibliotecário e a formação do leitor. In Barzotto, V. H. Estado da leitura (pp. 18-36). Campinas: Mercado das Letras, Associação de Leitura do Brasil.

Silva, J. L. C. (2020, 28 de outubro). Atuação das bibliotecas escolares em tempos de pandemia e pós-pandemia [Palestra]. Semana Nacional do Livro e da Biblioteca, Salvador, Bahia.

Silva, W. C. (2003). Miséria da biblioteca escolar. São Paulo: Cortez.

Souza, H. J. (2009). Como se faz análise de conjuntura (31. ed.). Petrópolis, RJ: Vozes.

\footnotetext{
${ }^{\mathrm{i}}$ Librarianship, here understood as the work of the librarian. In the case of state of Paraná, this professional is not present in school libraries.
} 
ii In this article, we reference the Paraná State Secretariat of Education in two ways: State Secretariat of Education and Sports, the nomenclature used since the 2019 management, and State Secretariat of Education, used before 2019. Both are identified with the same acronym - SEED.

iii https://recode.org.br/

iv N'Golo visited the quilombo to conclude a project of territorial and environmental management, executed in partnership with the Center of Alternative Agriculture of the North of Minas (CAA/NM) and the Dedicated Grant Mechanism for Indigenous Peoples and Local Communities organization, which resulted in a booklet about quilombola rights.

\section{Article Information \\ Received on June 19th, 2021 \\ Accepted on August 18th, 2021 \\ Published on October, 30th, 2021}

Author Contributions: The author were responsible for the designing, delineating, analyzing and interpreting the data, production of the manuscript, critical revision of the content and approval of the final version published.

Conflict of Interest: None reported.

Article Peer Review

Double review.

Funding

No funding.

How to cite this article

APA

Oliveira, D. C., Bufrem, L. S., \& Gehrke, M. (2021). Impacts and changes caused by the Covid-19 pandemic in librarianship: the rural school library scenario. Rev. Bras. Educ. Camp., $\quad 6, \quad$ e12478. http://dx.doi.org/10.20873/uft.rbec.e12478

ABNT

OLIVEIRA, D. C.; BUFREM, L. S.; GEHRKE, M. Impacts and changes caused by the Covid-19 pandemic in librarianship: the rural school library scenario. Rev. Bras. Educ. Camp., Tocantinópolis, v. 6, e12478, 2021. http://dx.doi.org/10.20873/uft.rbec.e12478 